Bangladesh J. Bot. 48(2): 271-278, 2019 (June)

\title{
EVALUATION OF ANTIMICROBIAL AND CYTOTOXIC EFFECTS OF FOUR TURKISH SPECIES OF ERYNGIUM L.
}

\author{
Berna Özbek Celik*, Emel Mataraci kara, Cagla Bozkurt Guzel, \\ Gülay Ecevit Genç ${ }^{1}$, Ilker Genç ${ }^{1}$, Sezin KurtoğLu Anil ${ }^{2}$ and Gulay MelikoĞlu ${ }^{2}$ \\ Department of Pharmaceutical Microbiology, Faculty of Pharmacy, \\ Istanbul University, Beyazit, 34116, Istanbul, Turkey
}

Keywords: Eryngium, Antibacterial, Antifungal, Cytotoxic, Herbal therapy

\begin{abstract}
The antimicrobial and cytotoxic effects of various endemic and non-endemic Eryngium species from Turkey were investigated. Nine endemic and two non-endemic Eryngium species were analyzed using a microdilution assay for their antibacterial and antifungal activities. Cytotoxic activities of E. pseudothoriifolium, E. thorifolium, E. davisii, and E. falcatum, on prostate carcinoma and endometrial cancer cells were analyzed by cytotoxic activity assay. It was observed that 16 out of 22 extracts (aerial or root part) showed antibacterial activities. Fifteen out of 22 extracts showed antifungal activity with the lowest MIC (156 mg/l) value against Candida albicans ATCC 10231 and C. tropicalis ATCC 750. Aerial parts of E. pseudothoriifolium, E. thorifolium, E. davisii, and E. falcatum exhibited cytotoxic effects on endometrial cancer cells. This evaluation of tested endemic Eryngium species' antimicrobial and cytotoxic activities is the first of its kind.
\end{abstract}

\section{Introduction}

The genus Eryngium L., belonging to the subfamily Saniculoideae of Apiaceae, is the largest and arguably the most taxonomically complex genus of the family Apiaceae. The genus has 250 species (317 taxa) in the world, which make it the most species rich genus of the Apiaceae (Pimenov 1993). The Eryngium species contain acetylenes, flavonoids, coumarins, and triterpene saponins. Eryngium taxa have a long tradition as a popular culinary and medicinal plant in the world (Paul et al. 2011). Some Eryngium species are used as folk medicine or ornamental plant and vegetables. Similarly, in Turkish folk medicine various species of the plant are used for a wide range of ailments fresh (Gümüş 1994, Sezik et al. 1997, Ertug 2000, Sezik 2001, Özgökçe and Özçelik 2004, Ozturk 2005, Tuzlacı 2005, Ecevit 2006). In particular, roots are used against various inflammatory disorders, sinusitis, colds, goiters, respiratory diseases, digestive diseases, and snake or scorpion bites as well as a diuretic and antitussive (Kupeli 2006, Mekhora 2012). Their leaves are used for infertility and as herbs for wound healing and treating kidney stones as well as food while fresh.

The authors aimed to investigate the antimicrobial effects of both aerial and root parts of nine endemic Eryngium species (E. isauricum Contandr. \& Quézel, E. kotschyi Boiss., E. trisectum Wörz \& H. Duman, E. bithynicum Boiss., E. davisii Kit Tan \& Yıldız, E. babadaghensis G.EcevitGenç, E.Akalın \& A.Wörz, E. polycephalum Hausskn. ex H.Wolff, E. thorifolium Boiss., E. pseudothoriifolium Contandr. \& Quézel) and two non-endemic Eryngium species (E. glomeratum Lam. and E. falcatum F. Delaroche) from Turkey were investigated. One of the non-endemic strains, E. glomeratum, is an east Mediterranean species, with a main distribution range in south

*Author for correspondence: <berna.ozbek@istanbul.edu.tr>, <bernaozbek@ hotmail.com>. ${ }^{1}$ Department of Pharmaceutical Botany, Faculty of Pharmacy, Istanbul University, Beyazit, 34116, Istanbul, Turkey. ${ }^{2}$ Department of Pharmacognosy, Faculty of Pharmacy, Istanbul University, Beyazit, 34116, Istanbul, Turkey. 
Turkey, Lebanon, Palestine, and Israel. Other strain, Eryngium falcatum, is a widespread species on coastal sand dunes and usually common along the Balkan coasts. Additionally, cytotoxic activities of E. pseudothoriifolium, E. thorifolium, E. davisii, and E. falcatum, which have more antimicrobial activities, on prostate carcinoma (PC-3) and endometrial cancer (ECC-1) cell lines at $12.5,25,100,250,500 \mathrm{~g} / \mathrm{ml}$ were analyzed by cytotoxic activity assay.

\section{Materials and Methods}

Plant materials were collected from different locations in Turkey. The species were collected and identified by G. Ecevit Genc and I. Genc, which were deposited in the Herbarium of the Faculty of Pharmacy, Istanbul University (ISTE), Turkey. The plant materials used in this study are listed in Table 1 . The root and the aerial parts of the plants were separated. The dried plant materials were percolated with methanol $(95 \%)$ at room temperature. The methanolic extracts (MEs) were evaporated to dryness under pressure and controlled temperature $\left(400-500^{\circ} \mathrm{C}\right)$ in a rotary evaporator. All the extracts were kept at $-20^{\circ} \mathrm{C}$ and then lyophilized. Crude methanolic extracts were obtained.

Table 1. The plant materials used in this study.

\begin{tabular}{|c|c|c|}
\hline Species & $\begin{array}{l}\text { Collection } \\
\text { data }\end{array}$ & $\begin{array}{l}\text { Collector } \\
\text { number }\end{array}$ \\
\hline E. falcatum & $\begin{array}{l}\text { Mugla, Fethiye Gidrak oition, 29. viii 2014, G. Ecevit Genc \& } \\
\text { I.Genc }\end{array}$ & IG 2282 \\
\hline E. thorifolium & $\begin{array}{l}\text { Muğla, Fethiye-Korkuteli road, Bayır village } 29 \text { viii 2014, G. } \\
\text { Ecevit Genc \& I.Genc }\end{array}$ & IG 2283 \\
\hline E. polycephalum & $\begin{array}{l}\text { Konya: Bozkir-Hadim road, Korualan, 28. viii 2014, G. Ecevit } \\
\text { Genc \& I.Genc }\end{array}$ & IG 2272 \\
\hline E. babadaghensis & $\begin{array}{l}\text { Muğla, Fethiye, Babadag, Esek Bayiltan position, 29. viii 2014, } \\
\text { G. Ecevit Genc \& I.Genc }\end{array}$ & IG 2281 \\
\hline E. davisii & $\begin{array}{l}\text { Konya: Bozkir-Hadim road, Korualan, Akdam plateau, 28. viii } \\
\text { 2014, G. Ecevit Genc \& I.Genc }\end{array}$ & IG 2273 \\
\hline E. bithynicum & Konya-Seydişehir road, 27. viii 2014, G. Ecevit Genc \&I.Genc & IG 2270 \\
\hline E. kotschyi & $\begin{array}{l}\text { Konya: Bozkir-Hadim road, Korualan, Akdam plateau, rocky } \\
\text { slopes, 29. viii 2014, G. Ecevit Genc \& I.Genc }\end{array}$ & IG 2274 \\
\hline E. trisectum & $\begin{array}{l}\text { Konya: Derebucak, Çamlik town, Kızıldağ,. 27. viii 2014, G. } \\
\text { Ecevit Genc \& I.Genc }\end{array}$ & IG 2271 \\
\hline E. isauricum & $\begin{array}{l}\text { Konya, Ermenek, Tepebaşi-Güzelyurt, } 29 \text { viii 2014, G. Ecevit } \\
\text { Genc \& I.Genc }\end{array}$ & IG 2277 \\
\hline E. pseudothoriifolium & $\begin{array}{l}\text { Muğla, Fethiye-Korkuteli road, Avlan village road, } 29 \text { viii } \\
\text { 2014, G. Ecevit Genc \& I.Genc }\end{array}$ & IG 2285 \\
\hline E. glomeratum & $\begin{array}{l}\text { Muğla, Fethiye, Babadağ road, 29. viii 2014, G. Ecevit Genc \& } \\
\text { I.Genc }\end{array}$ & IG 2279 \\
\hline
\end{tabular}

Antimicrobial activity of the crude methanolic extracts against Staphylococcus aureus ATCC 29213, Streptococcus epidermidis ATCC 12228, Escherichia coli ATCC 25922, Klebsiella pneumoniae ATCC 4352, Pseudomonas aeruginosa ATCC 27853, Proteus mirabilis ATCC 14153, Candida albicans ATCC 10231 and Candida tropicalis ATCC 750 were determined by 
the microbroth dilution technique using the Clinical and Laboratory Standards Institute (CLSI) recommendations (CLSI 2000a, CLSI 2000b). For the bacteria Mueller-Hinton broth, for yeast strains RPMI-1640 medium were used as the test medium. From $10000 \mathrm{mg} / \mathrm{l}$ crude extract in Mueller-Hinton broth or RPMI-1640 medium, serial two-folds dilution (5000 to $4.9 \mathrm{mg} / \mathrm{l})$ were prepared. The inoculum was prepared using a 4 - $6 \mathrm{hrs}$ broth culture of each bacterium and $24 \mathrm{hrs}$ culture of yeast strains adjusted to a turbidity equivalent to a $0.5 \mathrm{McFarland}$ standard, then diluted in broth media to give a final concentration of $5 \times 10^{5} \mathrm{cfu} / \mathrm{ml}$ for bacteria and $0.5 \times 10^{3}$ to $2.5 \times$ $10^{3} \mathrm{cfu} / \mathrm{ml}$ for yeast in the test tray. Well series with cefuroxime or ceftazidime antibiotics and an antifungal agent (clotrimazole) were also included to serve as positive controls. Antibiotic-free negative controls were also used. The trays were covered and placed into plastic bags to prevent evaporation. The trays containing Mueller-Hinton broth were incubated at $35^{\circ} \mathrm{C}$ for $18-20 \mathrm{hrs}$ and the trays containing RPMI- 1640 medium were incubated at $35^{\circ} \mathrm{C}$ for $46-50 \mathrm{hrs}$. The MIC was defined as the lowest concentration of compound giving complete inhibition of visible growth.

The cell culture medium for PC-3 and ECC-1 cell lines were Dulbecco's Modified Eagle's Medium (DMEM) (Winsent, St-Bruno, QC, Canada) supplemented with $10 \%$ heated fetal bovine serum (FBS) (Biochrome, Berlin, Germany) and 1\% penicillin-streptomycin solution (Winsent, St-Bruno, QC, Canada). Prepared media were filtered by $0.22 \mu \mathrm{m}$ sterile filter (Minisort, Sartorius, Germany). The PC-3 and ECC- 1 cells were cultured at $37^{\circ} \mathrm{C}$ under a humidified atmosphere containing 5\% $\mathrm{CO}_{2}$. According to protocol (Park 1994, McDaid 1999, Freshney 2000), cells were first cultured in 96-well plates at a density of $2 \times 10^{4}$ cells/well for $24 \mathrm{hrs}$. After incubation, the medium was changed, and the cells were treated with different concentrations of the plant extracts $(12.5,25,100,250,500 \mathrm{~g} / \mathrm{l}$ dilutions of the lyophilized extracts in dimethylsulphoxide [DMSO]). Following incubation for $48 \mathrm{hrs}$, cytotoxicity assays were carried out.

Cytotoxicity in the cells was monitored using MTT assay. Cells in their log growth phase were resuspended with trypsin $0.25 \%$-EDTA $10 \mathrm{mM}$. For the microtitration assay, $2.5 \times 10^{4}$ cells in $0.2 \mathrm{ml}$ of DMEM were seeded in each of the 96-well microtitre plates and incubated in a humidified atmosphere at $37^{\circ} \mathrm{C}$ for $24 \mathrm{hrs}$. At that time, when the cells were in the exponential phase of growth, different dilutions of the methanolic plant extracts, prepared in medium, were added (4 wells were used for each plant extract concentration to give quadruplicate determinations within each experiment). The 96-well microtitre plates were further incubated for 48 hour. Cellular growth control was performed using medium alone or with DMSO instead of plant extract. The DMSO concentration for the tested dilutions was not higher than $1 \%$, as in the solvent-control wells. Fresh medium then replaced the medium from all the wells, and the plate was further incubated for $24 \mathrm{hrs}$. Cell proliferation was evaluated with MTS/PMS (Cell Titer 96 Aqueous Non-Radioactive Cell Proliferation Assay, Cat.G5421-Promega). The medium of all the plates was removed and $100 \mu \mathrm{l}$ of fresh GM with $20 \mu \mathrm{l}$ of MTS/PMS (20:1) was added to each well. The plates, wrapped in aluminum foil, were incubated for $3.5 \mathrm{hrs}$ in a humidified atmosphere at $37^{\circ} \mathrm{C}$. Absorbance at $490 \mathrm{~nm}$ was recorded in a microplate reader (Bio-Rad, USA). The wells with medium and MTS/PMS without cells were utilized as blanks for the plate reader. The $\mathrm{IC}_{50}$ concentration was determined to be the plant extract concentration required to reduce the absorbance $(490 \mathrm{~nm})$ to half the control value.

\section{Results and Discussion}

According to previous studies, in vitro bioactivities such as cytotoxicity, against antiinflammatory, antimicrobial, antioxidant, and antihyperglycemic effects were demonstrated with Eryngium extracts. Ndip et al. (2007) showed that the methanolic extract form E. foetidum leaves showed moderate antibacterial activity against Helicobacter pylori (Ndip 2007). Another investigation on the leaf hydromethanolic extract of E. maritimun showed that using the 
microdilution method against food-borne pathogens and clinical isolates, exhibited antimicrobial activity (Meot-Duros 2008). Similarly, the antimicrobial activity of three other species belonging to genus Eryngium (E. creticum, E. campestre and E. thorifolium) were studied with the disc diffusion method against nine clinical strains of methicillin-resistant S. aureus (MRSA) (Celik 2011) and the essential oil obtained from E. thorifolium, which caused an inhibition zone ranging from 13 to $19 \mathrm{~mm}$ (similar to that exhibited by vancomycin), was demonstrated to be the most active species. According to the present results, it was observed that 16 of the 22 extracts (aerial or root parts) showed antibacterial activity with the lowest MIC $(78.1 \mathrm{mg} / \mathrm{l})$ value against tested Gram-positive bacteria ( $S$. aureus and S. epidermidis). Thirteen of the 22 extracts showed antifungal activity with the lowest MIC $(625 \mathrm{mg} / \mathrm{l})$ value against $C$. albicans and $C$. tropicalis. The MICs ranged from 0.22 to $5000 \mathrm{mg} / \mathrm{l}$. The microbial sensitivity to the different extracts represented by the mean MIC values ranged from 78 to $1250 \mathrm{mg} / \mathrm{l}$ (Table 2). E. falcatum was the most sensitive species (lowest MIC $=625 \mathrm{mg} / \mathrm{l}$ ), which has 8 activities against Gram-positive or Gram-negative bacteria. It was followed by E. thorifolium and E. pseudothoriifolium (both aerial and root parts), each of which had 6 antibacterial activities against Gram-positive or Gramnegative bacteria (lowest MIC $=78 \mathrm{mg} / \mathrm{l}$ ). Overall, in the present study the Gram-positive bacteria were more sensitive to the extracts than the Gram-negative bacteria. The cell walls of Grampositive bacteria compared with Gram-negative bacteria, are more sensitive to antimicrobial chemical compounds and even many herbal drugs. This may be because of inherent tolerance of Gram-negatives and the nature and composition of herbs. Having a complex cell wall, which acts as an effective permeability barrier to restrict the penetration of compounds and lipopolysaccharides layer and periplasmic space of Gram-negative bacteria are the reasons of relative resistance of Gram-negative bacteria (Sharifa 2008). Furthermore a set of multidrug resistance pumps in their cell wall extrudes toxins across the outer membrane (Tegos 2002). Similarly, Thiem et al. (2010) studied the antimicrobial activity of ethanolic extracts from leaves and roots of 3 Eryngium genera (E. planum, E. campestre, and E. maritimum) native to Poland, and these plants were tested by the method of series dilutions against different Gram-positive bacteria ( 2 strains) and fungi (5 species). The results have shown that the ethanolic extracts inhibit the growth of $S$. aureus and all tested fungi (Thiem 2010). The present results confirm that $E$. isauricum (root part), E. davisii (both aerial and root parts), E. falcatum (both aerial and root parts), and E. thorifolium (both aerial and root parts) exhibit a moderate antibacterial activity on Gram-positive strains of $S$. aureus and $S$. epidermidis. A weak antibacterial effect on $P$. aeruginosa was highlighted for E. davisii (root part), E. falcatum (root part), E. thorifolium (aerial part) and E. pseudothoriifolium (aerial part). Furthermore, the methanolic extracts from $E$. pseudothoriifolium (aerial parts and roots), E. trisecum (aerial part), and E. babadaghensis (root part) showed activity towards $P$. mirabilis with MIC values in the range of $1250 \mu \mathrm{g} / \mathrm{ml}$. The extract from aerial parts and roots of E. falcatum and the aerial part of E. thorifolium showed activity toward $K$. pneumoniae with MIC values in the range of $1250 \mu \mathrm{g} / \mathrm{ml}$. However, no activity was found with tested plants against $E$. coli.

Candida species with $C$. albicans -as the most common- are causal agents of opportunistic human infections. In addition, hospital-acquired infections by $C$. albicans have become a cause of major health concerns (Ferreira 2013). It was previously reported that many Eryngium species, like E. maritimum exerted antifungal activity against $C$. albicans and other strains (Abou-Jawdah 2002). Also, in an in vitro antimycotic activity screening against eight phytopathogenic fungi, $E$. creticum showed more than $95 \%$ inhibition of spore germination in at least two fungi (Yusuf 2002). According to the present results, aerial and root parts of E. kotschyi, E. glomeratum, E. davisii, E. thorifolium, and E. pseudothoriifolium having minimum MIC of $625 \mathrm{mg} / \mathrm{l}$ or $1250 \mathrm{mg} / \mathrm{l}$ were considered active against $C$. albicans and are summarized in Table 2. Also, E. 
babadaghensis (root part) and E. polycephalum (aerial part) had antifungal activity against $C$. albicans. On the other hand, the antifungal activity of the aerial and root extract of $E$. kotschyi and E. pseudothorifolium were $156.25 \mu \mathrm{g} / \mathrm{ml}$ against $C$. tropicalis. Additionally, the root part of $E$. isauricum and aerial part of $E$. bithynicum had moderate antimicrobial activity for $C$. tropicalis at $312.5 \mathrm{mg} / \mathrm{ml}$. More plants showed considerable antifungal activity against $C$. albicans than $C$. tropicalis.

Table 2. Antibacterial and antifungal effects of various endemic Eryngium species.

\begin{tabular}{|c|c|c|c|c|c|c|c|c|c|}
\hline Extracts & $\begin{array}{c}\mathrm{Sa} \\
\text { ATCC } \\
29213\end{array}$ & $\begin{array}{c}\text { Se } \\
\text { ATCC } \\
12228\end{array}$ & $\begin{array}{c}\text { Ec } \\
\text { ATCC } \\
25922\end{array}$ & $\begin{array}{c}\text { Ef } \\
\text { ATCC } \\
29212\end{array}$ & $\begin{array}{c}\text { Kp } \\
\text { ATCC } \\
4352\end{array}$ & $\begin{array}{c}\mathrm{Pa} \\
\mathrm{ATCC} \\
27853\end{array}$ & $\begin{array}{c}\text { Pm } \\
\text { ATCC } \\
14153\end{array}$ & $\begin{array}{c}\mathrm{Ca} \\
\mathrm{ATCC} \\
10231\end{array}$ & $\begin{array}{c}\mathrm{Ct} \\
\text { ATCC } \\
750\end{array}$ \\
\hline E. isauricum aerial & - & - & - & - & - & - & - & - & 156.25 \\
\hline E. isauricum root & 1250 & 1250 & - & - & - & - & - & 1250 & - \\
\hline E. kotschyi aerial & - & - & - & - & - & - & - & 1250 & 156.25 \\
\hline E. kotschyi root & - & 1250 & - & - & - & - & - & 1250 & 156.25 \\
\hline E. glomeratum aerial & - & - & - & - & - & - & - & 1250 & - \\
\hline E. glomeratum root & - & - & - & - & - & - & - & 1250 & - \\
\hline E. trisectum aerial & 1250 & - & - & - & - & - & 1250 & - & - \\
\hline E. trisectum root & - & - & - & - & - & - & - & - & - \\
\hline E. bithynicum aerial & - & - & - & - & - & - & - & - & - \\
\hline E. bithynicum root & - & - & - & - & - & - & - & - & 312.5 \\
\hline E. davisii aerial & 625 & 625 & - & - & - & - & - & 1250 & 312.5 \\
\hline E. davisii root & 625 & 1250 & - & - & - & 625 & - & 1250 & - \\
\hline E. falcatum aerial & 1250 & 1250 & - & - & 1250 & - & - & - & - \\
\hline E. falcatum root & 1250 & 625 & - & 625 & 1250 & 625 & - & - & - \\
\hline E. babadaghensis aerial & - & - & - & - & - & - & - & - & - \\
\hline E. babadaghensis root & - & - & - & - & - & - & 1250 & 1250 & - \\
\hline E. polycephalum aerial & - & - & - & - & - & - & - & 1250 & - \\
\hline E. polycephalum root & - & - & - & - & - & - & - & - & - \\
\hline E. thorifolium aerial & 78.12 & 312.5 & - & - & 1250 & 625 & - & 625 & - \\
\hline E. thorifolium root & 312.5 & 625 & - & - & - & - & - & 1250 & - \\
\hline E. pseudothoriifolium aerial & - & 625 & - & - & - & 625 & 1250 & 1250 & 156.25 \\
\hline E. pseudothoriifolium root & - & 312 & - & - & - & 625 & 1250 & 1250 & 156.25 \\
\hline Positive controls MIC & CXM & CXM & CXM & CXM & CXM & CAZ & CXM & CLT & CLT \\
\hline$(\mathrm{mg} / \mathrm{l})$ & 1.2 & 9.8 & 4,9 & 4.9 & 4.9 & 2.4 & 2,4 & 4.9 & 4.9 \\
\hline
\end{tabular}

Staphylococcus aureus American Type Culture Collection (ATCC) 29213 (Sa), Streptococcus epidermidis ATCC 12228 (Se), Escherichia coli ATCC 25922 (Ec), Klebsiella pneumoniae ATCC 4352 (Kp), Pseudomonas aeruginosa ATCC $27853(\mathrm{~Pa})$, Proteus mirabilis ATCC $14153(\mathrm{Pm})$, Candida albicans ATCC $10231(\mathrm{Ca})$, and Candida tropicalis ATCC 750 (Ct). CXM: Cefuroxime; CAZ: Ceftazidime; CLT: Clotrimazole.

There are few studies on the cytotoxic effects of Eryngium species but none for $E$. pseudothoriifolium, E. thorifolium, E. davisii and E. falcatum. According to the previous studies on Eryngium species, ethanol extracts of E. planum displayed cytotoxic activities to some leukemia cell lines (Bogucka-Kocka 2008). In another study by Zhang et al. (2008), 3 eryngiosides (eryngioside J, eryngioside L, and saniculasapoinin III) isolated from Eryngium yuccifolium were found to be mostly effective on human cancer cell line A-549 and normal cell line MRC-5, and they markedly inhibited the growth of pancreas cancer cell line PANC-1. Also, compounds isolated from the roots of Eryngium campestre showed weak cytotoxic activity against human tumor cell lines HCT 116 and HT-2923 (Kartal et al. 2005). Another study by Yurdakok 
and Baydan (2013) revealed that, aerial and root parts of E. maritimum and the endemic E. kotschyi induced cytotoxicity on Hep2, U138-MG, HepG2 and Vero cell lines in a dose-dependent manner with both LDH and MTT assays (Yurdakok and Baydan 2013). Similarly, in the present study, the anti-IC50 values for aerial parts of E. pseudothoriifolium, E. thorifolium, E. davisii, and E. falcatum on ECC-1 cells $(23.14,10.41,13.51$, and $22.72 \mathrm{mg} / \mathrm{ml}$, respectively) by MTT assay were found to be lower than the US National Cancer Institute recommendations (IC50<30 mg/l) to define the activity against cancer cells (Table 3). Following this fact, E. pseudothoriifolium, E. thorifolium, E. davisii, and E. falcatum aerial extracts examined in this study with observed IC50 values lower than $30 \square \mathrm{mg} / 1$ were considered to have significant activity on ECC-1 cells. However, it was also found that these extracts (aerial parts of E. pseudothoriifolium, E. thorifolium, E. davisii, and E. falcatum) had no cytotoxic activity on PC-2 at tested concentrations.

Table 3. IC50 values for aerial parts of the tested Eryngium spp. ( $\mathrm{mg} / \mathrm{ml})$

\begin{tabular}{lcccc}
\hline & E. pseudothoriifolium & E. thorifolium & E. davisii & E. falcatum \\
\hline *ECC-1 cells & 23.14 & 10.41 & 13.51 & 22.72 \\
$*$ PC-2 cell & $>30$ & $>30$ & $>30$ & $>30$ \\
\hline
\end{tabular}

*Endometrial cancer (ECC-1); prostate carcinoma (PC-3).

The present study showed that all endemic plants (E. isauricum Contandr. \& Quézel, E. kotschyi Boiss., E. trisectum Wörz \& H. Duman, E. bithynicum Boiss., E. davisii Kit Tan \& Yıldız, E. babadaghensis G. Ecevit-Genç, E. Akalın, \& A. Wörz, E. polycephalum Hausskn. ex H. Wolff, E. thorifolium Boiss., E. pseudothoriifolium Contandr. \& Quézel) could be a potential source for inhibitory substances for human pathogenic fungi and bacteria. Furthermore, aerial parts of E. pseudothoriifolium, E. thorifolium, E. davisii and E. falcatum induced cytotoxicity on ECC-1 cells with MTT assays.

\section{Acknowledgments}

This work was supported by Scientific Research Projects Coordination Unit of Istanbul University. Project number: 43682.

\section{References}

Abou-Jawdah Y, Sobh H and Salameh A 2002. Antimycotic activities of selected plant flora, growing wild in Lebanon, against phytopathogenic fungi. J. Agric. Food Chem. 50(11): 3208-3213.

Bogucka-Kocka A, Smolarz HD and Kocki J 2008. Ethanol extracts of E. planum displayed sitotixic activities to some leukemia cell lines. Fitoterapia 79(7-8): 487-97.

Celik A, Aydinlik N and Arslan I 2011. Phytochemical constituents and inhibitory activity towards methicillin-resistant Staphylococcus aureus strains of Eryngium species (Apiaceae). Chem. Biodivers 8: 454-9.

Clinical and Laboratory Standards Institute 2006. Methods for dilution antimicrobial susceptibility tests for bacteria that grow aerobically, 7th ed. approved standard M7-A7: CLSI, Wayne, PA.

Ecevit Genç G and Özhatay N 2006. An ethnobotanical study in Çatalca (European part of İstanbul) II. Turk. J. Pharm. Sci. 3(2): 73-89.

Ertuğ F 2000. An ethnobotanical study in central anatolia (Turkey). Econ. Bot. 54(2): 155-182. 
Ferreira AV, Prado CG, Carvalho-Dias KST and Dias ALT 2013. Candida albicans and non-C. albicans species: comparison of biofilm production and metabolic activity of biofilms, and putative properties of isolates from hospital environments and infections. Mycopathol. 175: 265-72.

Freshney RI 2000. Cytotoxity. In: Culture of animal cells. A manual of basic technique, $4^{\text {th }}$ ed, pp. $329-345$. Wiley-Liss, USA.

Gumus I 1994. Agrı yöresinde yetişen bazı faydalı bitkilerin yerel adları ve kullanılışları. Turk. J. Bot. 18: 107-112.

Kartal M, Mitaine-Offer AC, Abu-Asaker M, Miyamoto T, Calis I, Wagner H, and Lacaille-Dubois MA 2005. Two new triterpene saponins from Eryngium campestre. Chem Pharm Bull (Tokyo). 53: 1318-20.

Kupeli E, Kartal M, Aslan S and Yesilada E 2006. Comparative evaluation of the anti-inflammatory and antinociceptive activity of Turkish Eryngium species. J. Ethnopharmacol. 107(3): 32-37.

McDaid HM and Johnston PG 1999. Synergistic interaction between paclitaxel and 8-chloro-adenosi ne 3,5monophosphate in human ovarian carcinoma cell line. Clin. Cancer Res. 5: 215-220.

Mekhora C, Muangnoi C, Chingsuwanrote P, Dawilai S, Svasti S and Chasri K (Eds) 2012. Eryngium foetidum suppresses inflammatory mediators produced by macrophages, Asian Pac. J. Cancer Prev. 13: 653-664.

Meot-Duros L, Le Floch G and Magné C 2008. Radical scavenging, antioxidant and antimicrobial activities of halophytic species. J Ethnopharmacol. 116(2): 258-262

Ndip RN, Tarkang AEM, Mbullah SM, Luma HN, Malongue A and Ndip LM (Eds) 2007. In vitro antiHelicobacter pylori activity of extracts of selected medicinal plants from North West Cameroon. J. Ethnopharmacol. 114(3): 452-457.

Özgökçe F and Özçelik H 2004. Ethnobotanical aspects of some taxa in east Anatolia, Turkey I. Econ Bot. 58(4): 697-704.

Öztürk N and Dinç M 2005. Nizip (Aksaray) bölgesinin etnobotanik özellikleri. Ot Sistematik Botanik Dergisi. 12(1): 93-102.

Park JG, Lee SK, Hong IG, Kim HS, Lim KH and Choe KJ (Eds) 1994. MDR1 gene expression: Its effect on drug resistance to doxorubicin in human hepatocellular carcinoma cell line. JNCI: Journal of the National Cancer Institute. 86: 700-5.

Paul JH, Seaforth CE and Tikasingh T 2011. Eryngium foetidum L.: A review. Fitoterapia 82: 302-8.

Pimenov MG and Leonov MV 1993. The genera of the Umbelliferae: A nomenclator. $1^{\text {th }}$ ed. Royal Botanic Gardens: Kew.

Sezik E, Yeşilada E, Honda G, Takaishi Y, Takeda O, and Tanaka T 2001. Traditional medicine in Turkey X. folk medicine in central anatolia. J. Ethnopharmacol.75: 95-115.

Sezik E, Yesilada E, Tabata M, Honda G, Takaishi Y and Fujita T (Eds) 1997. Econ. Bot. 51(3): 195-211.

Sharifa AA, Neoh YL, Iswadi MI, Khairul O, Abdul Halim M and Jamalubin M (Eds) 2008. Effects of methanol, ethanol and aqueous extract of plantago majoron gram positive bacteria, gram negative bacteria and yeast. Annals of Microscopy 8: 42-44.

Tegos G, Stermitz FR, Lomovskaya O and Lewis K 2002. Multidrug pump inhibitors uncover remarkable activity of plant antimicrobials, Antimicrob. Agents Chemother 46: 3133-3141.

Thiem B, Goślińska O, Kikowska M, and Budzianowski J 2010. Antimicrobial activity of three Eryngium L. species (Apiaceae). Herba polonica 56(4): 52-8.

Tuzlacı E 2005. Geçmişten günümüze Bodrum'da bitkiler ve yaşam. $1^{\text {th }}$ edition, pp. 1-251. Güzel Sanatlar Matbaas1, İstanbul.

Yusuf, AJ, Hana S and Abdu S 2002. Antimycotic activities of selected plant flora, growing wild in Lebanon, against phytopathogenic fungi. J. Agric. Food Chem. 50(11): 3208-3213.

Zhang Z, Li S, Ownby S, Wang P, Yuan W and Zhang W (Eds) 2008. Phenolic compounds and rare polyhydroxylated triterpenoid saponins from Eryngium yuccifolium. Phytochemistry 69(10): 2070-80. 